\title{
Seasonal Variation in Rectal Temperature of Holstein Friesian Cattle in The Guinea Savanah Zone of Nigeria
}

\author{
MUSA-AZARA ${ }^{1 *}$, S.I., OGAH ${ }^{1}$, .D.M. and YAKUBU ${ }^{2}$, A
}

1.Department of Animal Science, college of Agriculture, Lafia, Nasarawa State, Nigeria.

2.Dept of Animal Science, Faculty of Agriculture, Nasarawa State University, Nigeria. EMAIL -_dribmazara@yahoo.com

\section{INTRODUCTION}

When environmental temperature move out of the thermo neutral zone (comfort zone), dairy cattle begin to experience either heat stress or cold stress. In cold stress, the cow is required to increase the amount of energy used to maintain the body temperature and that means less energy available to produce milk. Thermo neutral zone is the range of environmental temperature where normal body temperature is maintained and heat production is at the basal level (Yousef, 1985). Heat stress for the dairy cow can be understood to indicate all high temperature related forces that induce adjustments occurring from the sub-cellular to the whole animal body to help the cow avoid physiological distinction and for it to better fit its environment (Kadzere et al., 2002).

Exposure of cattle to thermal stress leads to physiological responses such as the elevation of rectal temperature, respiratory rate and pulse rate with concomitant decline in feed intake and production. The components of the thermal environment which are involved in heat stress are temperature, humidity, wind speed, solar radiation and rainfall (Kabuga, 2005).

Dairy cattle produce milk more efficiently in environments where they can maintain their body temperature at around $38^{\circ} \mathrm{C}($ Stokka et al., 1998). Tissue and cellular metabolism and the underlying biochemical reactions that sustain life and production need narrow limits. Relatively small increases in body temperature of at least $1^{\circ} \mathrm{C}$ result in detectable, deleterious effects in metabolism and tissue integrity, in particular, the breakdown of body protein and a significant depression in production (Smith and Mathewman, 2000). Heat stress is a result of an imbalance between heat gain and heat dissipation in an animal (Wayner, 2001). The primary factors that can cause heat stress in dairy cows are high environmental temperatures and high relative humidity (West, 1995).

Heat stress affects two of the most economically important segments of the dairy farm business, milk production and reproduction (Wayner, 2001). On the other hand, there is a reduction in feed intake associated with a decrease in milk production (Kabuga, 2005). To boost agriculture, increase animal protein production and alleviate poverty, private individuals and governments import exotic breeds of cattle. However, the anicipated benefits are not derived either due to diseases or environmental factors, of which temperature is one. The aim of this study was to evaluate the effects of variation in seasonal enviromental temperature on rectal temperatures of Holstein Fresian cattle imported to Nigeria for dairy production.

Key Words: Rectal temperature, season, Holstein Friesian, Savannah, Nigeria.

\section{MATERIALS AND METHODS}

The study was performed on Holstein Friesian cattle in Nagari farms located in the Northern Guinea Savanah zone of Nigeria. Rectal temperature of twenty Friesian cows were measured at $07.00 \mathrm{hr}$ and at $14.00 \mathrm{hr}$ using a digital thermometer after the animals had been accustomed to the experimental procedures for a period of 2 weeks. The animals were managed under semi intensive system. They were housed under a shed with concrete floor at night. Three to four years old lactating cows were used for the study. The animals were fed on established pasture (grasses and legumes), hay, silage and concentrates. All animals were apparently healthy at the time of experiment. The data was collected during cold and hot dry seasons respectively.

Temperature measurement was done daily for a period of 7 days. Data collected were subjected to analysis of variance using the appropriate sub-routine of SAS (1999) statistical packages. Means separation was 
carried out using Least Significant Difference (LSD) method on the level $\mathrm{P}$ $<0.0 .5$.

\section{RESULTS}

Data obtained from measurement of rectal temperature at $07.00 \mathrm{hr}$ and at $14.00 \mathrm{hr}$ using twenty Friesian cows are being presented (Tables I-III). Mean rectal temperatures, minimum and maximum together with standard errors are shown on table I and II. Mean morning temperature of $38.2^{\circ} \mathrm{C}$ was recorded during cold and $38.87^{\circ} \mathrm{C}$ in the hot dry season. Mean afternoon temperature of $38.8^{\circ} \mathrm{C}$ was recorded during the cold season while $39.05^{\circ} \mathrm{C}$ was obtained during the hot-dry season. They describe the extent of temperature fluctuation during the cold and hot-dry season respectively. The mean morning rectal temperature were $38.2 \pm 0.3$ and $38.87 \pm 0.09(\mathrm{P} 0.0<5)$ while the afternoon temperature were $38.8 \pm 0.05$ and $39.05+0.05(\mathrm{P}<0.05)$ for the cold and hot-dry seasons respectively. In both seasons, mean $14.00 \mathrm{hr}$ temperature was significantly higher $(\mathrm{P}<0.05)$ than mean 07.00hr temperature.

Seasonal variation in rectal temperature was significant, being higher during the hot season than the cold season (Table III). Table IV shows the record weather conditions during the cold and hot seasons in the study area. This result describes the seasonal fluctuation in rectal temperature of a temperate breed of cattle, Holstein Friesian in the Nigerian Guinea Savanah zone of Nigeria.

TABLE I: Variations in rectal temperature of Holstein Friesian during the cold season (Mean + SE)

\begin{tabular}{|c|c|c|c|c|c|c|}
\hline \multirow[b]{2}{*}{ Day } & \multirow{2}{*}{$\begin{array}{c}\text { Morning } \\
\text { Mean + SE }\end{array}$} & \multicolumn{5}{|c|}{ Afternoon } \\
\hline & & Min & Max & Mean + SE & Min & Max \\
\hline 1 & $38.63+0.09$ & 38.20 & $39: 10$ & $38.70+0.07$ & 38.40 & $39: 20$ \\
\hline 2 & $38.63+0.11$ & 38.00 & $39: 10$ & $38.49+0.13$ & 38.70 & $39: 20$ \\
\hline 3 & $38.68+0.09$ & 38.30 & $39: 20$ & $38.55+0.08$ & 38.20 & $39: 10$ \\
\hline 4 & $38.54+0.05$ & 38.20 & $38: 80$ & $38.63+0.08$ & 38.20 & $39: 10$ \\
\hline 5 & $38.67+0.16$ & 38.90 & $39: 80$ & $38.79+0.16$ & 38.10 & $39: 90$ \\
\hline 6 & $38.66+0.08$ & 38.30 & $39: 10$ & $38.76+0.07$ & 38.40 & $39: 10$ \\
\hline 7 & $38.67+0.08$ & 38.30 & 39.10 & $38.76+0.09$ & 38.40 & 39.20 \\
\hline
\end{tabular}

TABLE II: Variations in rectal temperature of Holstein Friestian cattle during the hot-dry season (mean + SE)

\begin{tabular}{|lllllll|}
\hline Day & $\begin{array}{c}\text { Morning } \\
\text { Mean + SE }\end{array}$ & Min & Max & $\begin{array}{c}\text { Afternoon } \\
\text { Mean + SE }\end{array}$ & Min & Max \\
\hline 1 & $38.39+0.18$ & 37.00 & $39: 90$ & $39.40+0.24$ & 39.40 & $39: 6$ \\
2 & $38.32+0.12$ & 38.00 & $39: 10$ & $39.54+0.30$ & 39.50 & $39: 6$ \\
3 & $38.16+0.11$ & 37.60 & $39: 70$ & $38.55+0.08$ & 38.20 & $39: 10$ \\
4 & $38.06+0.28$ & 38.00 & $38: 70$ & $38.64+0.08$ & 38.20 & $39: 20$ \\
5 & $38.67+0.16$ & 37.90 & $39: 80$ & $39.60+0.16$ & 38.10 & $39: 90$ \\
6 & $38.66+0.08$ & 38.30 & $39: 10$ & $38.76+0.07$ & 38.40 & $39: 10$ \\
7 & $38.31+0.18$ & 38.00 & $39: 90$ & $38.14+0.09$ & 38.30 & $39: 40$ \\
\hline
\end{tabular}

TABLE III: Effect of season on rectal temperature of Holstein Friesan

\begin{tabular}{|lllllll|}
\hline Time & \multicolumn{3}{c}{ Cold season } & \multicolumn{3}{c|}{ Hot-Dry Season } \\
& Mean & SD & SE & Mean & SD & SE \\
\hline Morning & $38.19 \mathrm{~b}$ & 1.55 & 0.13 & $38.87 \mathrm{a}$ & 1.12 & 0.09 \\
Afternoon & $38.80 \mathrm{~b}$ & 0.56 & 0.05 & $38.05 \mathrm{a}$ & 0.63 & 0.05 \\
\hline
\end{tabular}

*Means within the same row bearing different superscripts differ significantly $(P<0.05)$. 
Nigerian Veterinary Journal 201031 (3)

TABLE IV: Mean relative humidity and ambient temperature during the study period.

\begin{tabular}{|llcc|}
\hline Period & Rel. Humidity (\%) & Min. temp (OC) & Max Temp (OC) \\
\hline Cold (Dec-Feb) & 53 & 21.5 & 36.5 \\
Hot Dry Season (Mar.-Jun.) & 54 & 26.5 & 39.8 \\
\hline
\end{tabular}

Source: NIMET,(2001). Synoptic office Lafia, Nasarawa state.

\section{DISCUSSION}

The results of this study indicates that rectal temperature values of the Holstein Friesian cattle were within normal range established for the species (Radostits et al., 2000). Distinct diurnal variation in rectal temperature was observed. Variations of rectal temperature with ambient temperature and hour of the day have earlier been reported in other species (Igono et al., 1983, Ayo and Sinkelu, 2007). In both seasons, the mean afternoon (14.00hr) body temperature was significantly higher than early morning $(07.00 \mathrm{hr})$ temperatures. The mean temperatures were also significantly higher $(\mathrm{P}<0.05)$ during the hot dry season compared to the cold season. Meteorological data from the study area indicated higher ambient temperatures during the hot dry season (NIMET). The findings of this research are in agreement with earlier reports that rectal temperature

\section{REFERENCES}

AYO, J.O. and SINKELU .V.O. (2007). Effect of Ascobic Acid on Diurnal Variation in Rectal Temperature of Shaver Broom Pullets during the Hot Dry Season. International Journal of Poultry Science 6(9): 642-646.

ACEVES .C, ROMERO. C, SAHAGUN. L and VALVERDE R(1987) Thyroid Hormone Profile in Dairy Cattle Acclimated to Cold or Hot Environmental Tempera-ture. Europ. J.. Endocrinology, vol. 114, issue 2.

IGONO, M.O, MOLOKWU .EW.C. ALIYU Y.OO. (1983). Seasonal Variations in Rectal Temperature of Yankasa Sheep. Veterinary Research Communications, 6223-226.

KABUG, J.D (2005) .The Influence of Thermal Conditions of Rectal Temperature, Respiration and Pulse Rate of Lactating Holstein Friesian Cows in Humid Tropics. Inter.J. Biometeo-rology. Vol. 36 No. 3.

KADZERE, C.I MURPHY M.R., SILANIKOVE, N (2002). Heat Stress in Lactating Dairy Cows. Livestock production Science 77. 59-91.

MC DOWELL, R.E. HOOVEN, N.W., CAMOEW J.K (1976). Effects of Climate on Performance of is an indicator of thermal balance and may be used to assess the adversity of the thermal environment (McDowell et al., 1976).

Ambient temperatures in the study area, particularly during the hot-dry season are outside the thermo neutral zone $\left(18-28^{\circ} \mathrm{C}\right)$ for the dairy cattle (Aceves et al., 1987). The animals are therefore required to increase the amount of energy used to maintain body temperature and there is less energy available to produce milk. Under such conditions milk yield and quality are adversely affected. The findings of this research highlight the need for farmers importing exotic dairy breeds to adapt management practices that ameliorate the effect of heat stress particular during the hot season. It is suggested that thermal stress be alleviated by use of shade in addition to sprinkler and fan cooling systems.

Holstian in First Lactation. J. Dairy Sci, 1976, 59, 965-973.

NIMET, (2001)Nigerian Ministry of Aviation,Synoptic office Lafia,Nasarawa state.

RADOSTITS,O.M, GAY .C.C, BLOOD D.C. and KENNETH, WIH (2000). Veterinary Medicine. $9^{\text {th }}$ Eds. Book Powers,

SMITH, A.J. and MATHEWMAN. R.W. (2000). Aspects of Physiology and Metabolism of Dairy cows kept at high ambient temperature. J. Topical Anim. Health and Prod. Vol. 18 No 4. 1986.

STOKKA, G.T. SMITH J, HARNER D., DUNHAM, J. AND MEGRIMS, (1998). Heat Stress in Feed of Cattle. Kamsas Veterinary quality. 3-1988.

WAGNER, P.E (2001). Heat stress in Dairy cows. Dairy Franklin country publisher, USA.

WEST,J.W (1995). Managing and Feeding lactating Dairy cows in hot weather United States Department of Agriculture.

YOUSEF, M.K (1985) basic principle. Stress physiology in livestock. Vol. 1. CRC Press. Boca Raton, FC. 